There is no definite evidence that the fungus attacks living trees; but field observations have shown an initial infection of wounds in standing trees.

Sometimes the Chalaropsis and more frequently the accompanying Ceratocystis spp. are parasitized by Gonatobotryum fuscum Sacc., its parasitism showing some similarity to that of Gonatorrhodiella highlei A. L. Sm. on Nectria ${ }^{3}$.

Birkbeck College,

M. VINCENT

Malet Street,

London, W.C.1.

$$
\text { Oct. } 30 .
$$

${ }^{1}$ Hamond, Trans. Brit. Mycol. Soc., 19 (1935).

${ }^{2}$ Davidson, Mycologia, 36 (1944).

${ }^{3}$ Blyth, Trans. Bot. Soc, Edin., 35 (1950).

\section{Chemical Mutagenesis in Bacteriophage T2}

Proflavine (2-8 diamino acridinium sulphate, Abbott) in concentrations of $3-4 \gamma / \mathrm{ml}$. prevents liberation of infectious bacteriophage $T 2$ from Escherichia coli, strain $B$, without preventing lysis ${ }^{1}$. The bacteria liberate incomplete non-infectious phage particles ${ }^{2}$. If proflavine is removed before lysis, the yield of complete phage is normal or subnormal. We have detected a mutagenic effect on phage produced in proflavine-treated bacteria.

$E$. coli $B$ was infected with phage $T 2$ in a synthetic medium (glucose, 4 gm. ; ammonium chloride, 1 gm. ; magnesium sulphate, $0.12 \mathrm{gm}$. ; disodium hydrogen phosphate, $6 \mathrm{gm}$.; potassium dihydrogen phosphate, $3 \mathrm{gm}$.; water, $1,000 \mathrm{ml}$; $p \mathrm{H} 7 \cdot 0$ ), with or without $4.0 \mathrm{r} / \mathrm{ml}$. proflavine added at the time of infection. Proflavine was removed $17 \mathrm{~min}$. after infection by a $1: 100$ dilution. The phage yield from proflavine-treated cultures contained many more plaque-type mutants $r$ and $w$ (see ref. 3) than the control phage yield (see table).

\begin{tabular}{|c|c|c|c|c|c|c|}
\hline & \multicolumn{6}{|c|}{ Mutants $r$ and $w$ in bursts of phage $T 2$} \\
\hline & $\begin{array}{l}\text { No. of } \\
\text { plates }\end{array}$ & $\begin{array}{l}\text { Average } \\
\text { No. of } \\
\text { bursts } \\
\text { per plate }\end{array}$ & $\begin{array}{l}\text { No. of } \\
\text { bursts } \\
\text { cxam- } \\
\text { ined }\end{array}$ & $\begin{array}{l}\text { Plates } \\
\text { with } \\
\text { mut- } \\
\text { ants }\end{array}$ & $\begin{array}{l}\text { Total } \\
\text { yield }\end{array}$ & $\begin{array}{l}\text { Total } \\
\text { mnit- } \\
\text { ants }\end{array}$ \\
\hline $\begin{array}{l}\text { Exp. } 1 \\
\text { Control } \\
\text { Proflavine } \\
4 \cdot 0 \gamma / \mathrm{ml} .\end{array}$ & $\begin{array}{l}100 \\
100\end{array}$ & $\begin{array}{l}2 \cdot 7 \\
2 \cdot 65\end{array}$ & $\begin{array}{l}270 \\
265\end{array}$ & $\begin{array}{r}1 \\
43\end{array}$ & $\begin{array}{l}25,000 \\
26,000\end{array}$ & $\begin{array}{r}15 \\
201\end{array}$ \\
\hline $\begin{array}{l}\text { Exp. } 2 \\
\text { Control } \\
\text { Protlavine } \\
4.0 \mathrm{\gamma} / \mathrm{ml} .\end{array}$ & $\begin{array}{l}40 \\
42\end{array}$ & $\begin{array}{l}4 \cdot 1 \\
4 \cdot 3\end{array}$ & $\begin{array}{l}165 \\
180\end{array}$ & $\underset{28^{*}}{2}$ & - & $\begin{array}{r}9 \\
123\end{array}$ \\
\hline
\end{tabular}

* Four plates had mutants of two distinct plaque types.

The mutants include the same variety of plaque types as the spontaneous mutants. In the yields from individual bacteria the mutants are distributed in clones, with distribution of clone size roughly similar to that observed with spontaneous mutants ${ }^{4}$. The effect of proflavine appears, therefore, to be an increase in mutation-rate over the rate of spontaneous mutations. Experiments directed towards detecting any selection by proflavine in favour of plaque-type mutants were negative. There was no preferential loss of clones containing $r^{+}$phage only, nor any inerease in the proportion of $r$ particles in the yield of bacteria infected mixedly with $T 2 r^{+}$ and $T 2 r$.
Proflavine increased the frequency of $r$ mutants in a $T 2 w$ stock. In presence of proflavine, the rate of the mutation $T 2 r \rightarrow T 2 r^{+}$was not increased enough over the spontaneous rate (about $10^{-7}$ ) to allow detection of any $r^{+}$mutants among $3 \times 10^{4} r$ particles from proflavine-treated bacteria. Preliminary experiments indicate a slight effect of proflavine on the mutation $T 2 \rightarrow T 2 h$.

Proflavine is an effective mutagen for bacteria. Treatment of washed cells of a streptomycin-dependent strain of $E$. coli ${ }^{5}$ with 4.0-20.0 $\mathrm{\gamma} / \mathrm{ml}$. proflavine $\left(1 \mathrm{hr}\right.$. at $37^{\circ} \mathrm{C}$. in distilled water) produces no sterilization of bacteria but increases 6-10 times the number of colonies they produce on nutrient agar without streptomycin.

This work was done under a predoctoral fellowship from the National Foundation for Infantile Paralysis and under the direction of Prof. S. E. Luria ; it was supported in part by a grant from the American Cancer Society (upon recommendation of the Committee on Growth).

\section{Robert I. DeMars}

Department of Bacteriology, University of Illinois, Urbana, Illinois. June 4.

${ }^{2}$ Fitzgerald, R. J., and Lce, M. E., J. Immun., 52, 127 (19+6). Foster, R. A. C̈., J. Bact., 56, 795 (19 18$)$.

2 DeMars, R. I., Luria, S. E., Fisher, H., and Levinthal, C., Ann. Inst. Pasteur, 84, 113 (1953).

${ }^{3}$ Hershey, A. D., Cold Spring Harb. Symposium Quant. Biol., 11, 67 $(1946)$.

${ }^{4}$ Luria, S. E., Cold Spring Harb. Symposium Quant. Biol., 18, 463 (1951).

- Bertani, G., Genetics, 36, 598 (1951).

\section{Eye Movements in Connexion with Television Viewing}

THE present-day British system of television makes use of the line interlace system whereby rames, each containing only half the total picture information, are presented at the rate of 50 per sec. The advantage of this system compared with the sequential system, in which each frame contains the total picture information, is that it gives a subjective increase in the maximum amount of information that can be transmitted in a given band-width. A disadvantage of the interlace system is that pictures of still objects may show instability associated with the interlace, and those of vertically moving objects may appear non-interlaced with the raster drifting slowly in the direction of movement (that is, 'crawling'). Gouriet ${ }^{1}$ has suggested that differences in the pattern of eye movement when viewing sequential and interlaced pictures could account for these phenomena.

Using the photoelectric corneal reflex apparatus ${ }^{2}$, an investigation of the problem has therefore been made. Records have been obtained of the movements of one eye for binocular viewing of a 9 -in. television screen for both sequential and interlaced scan with the picture present and with the picture suppressed. Viewing distances of $34 \mathrm{~cm}$. and $120 \mathrm{~cm}$. were used. The latter distance was the minimum for direct viewing that the configuration of the apparatus would allow; for the shorter distance, the subject viewed an image of the screen formed by reflexion in a plane mirror. Records for fixation of a pointer moving vertically across the screen for both sequential and interlaced scan with picture suppressed have also been obtained for the longer distance. 